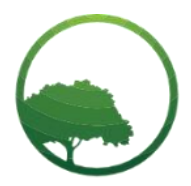

Research in Business \& Social Science

IJRBS VOL 10 NO 3 ISSN: 2147-4478

\title{
Effect of demonetization on microfinance industry in India
}

\author{
(D) Kishore Kumar Das ${ }^{(a) *}$, (D) Shahnawaz Ali(b) \\ ${ }^{(a)}$ Associate Professor \& Head, Department of Commerce \& Department of Business Administration, Ravenshaw University, Cuttack-753003, \\ Odisha, India \\ ${ }^{(b)}$ Lecturer \& Head of Department (Finance \& Accounts) at Catholic University in Erbil, 753003, Kurdistan Region, Iraq
}

\author{
ARTICLE INFO \\ Article history: \\ Received 08 March 2021 \\ Received in rev. form 14 April 2021 \\ Accepted 15 April 2021 \\ Keywords: \\ Micro-finance, Payment Banks, \\ Financial Inclusion, Demonetization, \\ Cashless Economy, Self-helf Group \\ JEL Classification: \\ B27
}

\begin{abstract}
A B S T R A C T
High-value denomination currency was scrapped off from the Indian economy on 8th November 2016, Rs. 500 and Rs. 1,000 currency notes were declared invalid at midnight hour. Taking such a bold step by Hon. Prime Minister of India Mr. Narendra Modi, means declaring $86 \%$ of cash in circulation an illegal tender overnight. This study is conducted on the immediate effect of demonetization on the microfinance industry in India and its after-effects in the later years. We have analyzed the data collected from the rural sector, on the collections and lending, impact on the farmers, how it has affected the small microfinance companies. We have also analyzed RBI's initiative towards financial inclusion, Pradhan Mantri Jan Dhan Yojana (PMJDY), the emergence of new Small Finance Banks, Digital Banks, Payment banks, etc. We have critically analyzed the impact of cost versus the benefit from the demonetization exercise for the rural and microfinance industry. The aim of this study is to analyze the overall financial inclusion of the rural and small sectors towards the dream of a Cashless Economy.
\end{abstract}

(C) 2021 by the authors. Licensee SSBFNET, Istanbul, Turkey. This article is an open access article distributed under the terms and conditions of the Creative Commons Attribution (CC BY) license (http://creativecommons.org/licenses/by/4.0/).

\section{Introduction}

On $8^{\text {th }}$ November, 2016, the Prime Minister of India made an important announcement, which changed not only the course of the financial industry, but the overall economy of the country. The Government declared ₹500 and ₹ 1,000 denominated currency as invalid overnight. Demonetization was not new to Indian economy; similar measures were taken twice in the recent past. The government had not just one reason to declare its highest currency of ₹ 1,000 and ₹500 to be invalid. One of the main reason for demonetization is to curb black money, and control terrorism, inflicting losses to the criminals having black money in high denominated currencies. Another main reason for demonetization was to bring India close to a digital and cashless economy. Ewallets and digital payments apps like Paytm, have made tremendous growth post announcement of demonetization, whereas other sectors like Microfinance Institutions (MFI) and agricultural sectors faced a major blow during this period.

Microfinance industry (MFI) is deeply rooted in the semi-urban and rural parts of the country, and most of the people using microfinance industry belong to the uneducated mass, who know nothing about the use of computers and digital banking. MFIs do collection on daily, weekly or monthly basis, and that too majority of their collections are in small cash amounts. demonetization had an immediate adverse effect on the economy. There was liquidity crunch among the people, especially rural segment of the society, who are nascent to banking system and deal with cash only. The worst affected were Non-Banking Micro-Finance Industry, however they were rewarded later with banking license from RBI. Business Standard reported based on data published by Microfinance Institutions Network (MFIN), that loan Portfolio at Risk (PAR) for delinquencies of more than 30 days (PAR>30) was almost $6 \%$ at the end of December 2017, up $0.3 \%$ against December 2016, soared to as high as $14.1 \%$ by the end of march 2017 . In this study we have done extensive study on cause, effect and benefits of demonetization on the future of Indian economy. The objective of this study is to understand the challenges faced by microfinance industry in India, post demonetization. We have also studied the various

* Corresponding author. ORCID ID: 0000-0002-4971-7884

(C) 2021 by the authors. Hosting by SSBFNET. Peer review under responsibility of Center for Strategic Studies in Business and Finance. https://doi.org/10.20525/ijrbs.v10i3.1105 
challenges faced in financial inclusion and challenges faced by MFIs after demonetization. Also there is an effort to understand the impact on lending by MFIs during the demonetization period.

\section{Theoretical Background}

Related studies show familiarity with the body of knowledge and gives an idea of studies already conducted in the area. Our study is to analyze the impact of demonetization on micro-finance sector, however we have studied the existing literature by Rastogi (2018) who has justified the timing of demonetization, because the economy was performing well, it was capable of handling short term shocks. He also discussed the reasons and impact of demonetization on black money, fake currency, terror financing, note bank politics, economic growth of India. Bansal, N (2019) in his study on impact of demonetization on banking sector has given a very positive findings, he suggested that demonetization has reduced black money circulation in the economy, and in long run it will improve the fiscal deficit, control inflation, reduce corruption, eliminate counterfeit currency, improve tax compliance and overall lead to a sustainable and stable economy. Kamala Devi, L.K., \& Rajavalli Devi, L.K. (2018) has shown the positive aspect of demonetization by including through various financial inclusive schemes for the poors and the deprived. In their research, they have shown that number of digital transactions post demonetization has significantly increased in the rural areas, the number of digital payment systems like NEFT, IMPS, PPIs, Mobile Banking has shown significant increase in post demonetization. More people have started using more of financial services after demonetization. There has been huge shift from non-user to first time users increasing the financial inclusion in the country. Radhika et all (2017) have done an extensive study on the immediate impact of demonetization on the micro-finance sector, and its scope of financial inclusion in long run. They have concluded that although demonetization has had a very hard-hitting impact on the growth of Indian economy from 9.7\% to 5.7\% within one year, however, it's a short-term impact, paving way for a long run benefit of financial inclusion through bringing the economically backward class of people to the mainstream of digitalization and use of digital banking, mobile wallets. Micro-Finance Institution (MFI) were very unorganized and carry the risk of holding cash, but post demonetization the MFIs are more organized, transparent and using modern technologies for operating the company.

Taruna \& Kumar, N (2017) have shown the immediate impact of demonetization on the rural sector of Lucknow. They reasoned for an adverse effect of demonetization on the poors and came up with an explanation that it was all because of improper implementation of such a beautiful policy. The long-term benefits are yet to be seen, but the poors of rural areas are very badly impacted, because they were only dependent on cash currency for their day-to-day work. When Taruna et all projected that only poors of rural parts were very badly impacted, Sinha, A \& Rai, D (2016) said that all strata of life came to a standstill, by withdrawing $86 \%$ of circulating currency with a blink of time. They too blamed for inadequate and improper planning on government's part for implementing demonetization. Shahare V. B. (2017) emphasized in his research for the need of demonetization to fight black money, however he blamed for the lack of proper planning and inadequate measures for implementation of this policy. He said that agrarian economy, which is majorly dependent on cash and is way far from understanding the concept of digital currency, had to face the roughest challenge post demonetization. He proposed to strengthen and empower the Microfinance sector with digital payments mechanism. Use of government schools like Anganwadi, colleges, panchayats to create awareness among the rural section and deprived section of the society, about use of digital banking and payment mechanism. Krishnan, D \& Siegel, S (2017) did a survey in 28 slum or lower income neighborhoods in Mumbai. According to their findings, post demonetization lead to drop in average income level of $10 \%$ in the month of December, 2016. This drops in income lead to further drop in consumption as well as change in family's savings. Also, an increase in banking transactions increased with corresponding decline in use of cash for day-to-day transaction. Abhijeet Banerjee et al (2019) did an experimental research on how should information be disseminated to large populations, especially during the chaotic 2016 demonetization. They varied how information about the policy was delivered to the villages along two dimensions, and how people were initially informed (broadcasting vs seeding) and whether the identities of the initially informed were publicly disclosed (common knowledge). They concluded through the field experimental study, that broadcasting message could be useful for simple messages, but for complex message like digital banking and cashless economy, seeding is the best option for spreading information.

This research is based on secondary data collected from various sources like indexed journals, books, published articles on news website, RBI website and other government websites. This research has also analysed some observations and interactions with people in the aftermath of demonetization. The period of the study is in between November 2016 to October, 2019.

\section{Demonetization and micro-finance industry}

Microfinance is aimed at providing banking and financial services to the ones, who are not eligible access conventional banking and financial services in an economy. It is promoted by the central bank with the aim of financial inclusion of the weaker and deprived section of the society. By integration of micro-finance industry with conventional banking in the economy, Reserve Bank of India (RBI) aims to build a strong, robust and efficient financial system in the country. In today's scenario, Microfinance Industry (MFI) holds significant share of economy, and comes under the regulations of RBI. As per the data from Care Ratings (2017), there are 71 MFIs registered with RBI.

Just a month before Demonetization, the gross total loan portfolio of Non-Banking Financial Corporation (NBFC-MFI) stood at Rs. 55,254 crores with more than $99 \%$ of collection rate. With the government announcing demonetization in November, 2016, the 
microfinance industry witnessed a major blow to its collections, and loan repayments. NBFC-MFIs comes second largest source of micro-credit in the country. A month after announcement of demonetization, the number total loan disbursed by NBFC-MFI dropped by $26 \%$ in the quarter ending $30^{\text {th }}$ December, 2016. The decline trend continued to the next financial year 2016-2017, the decline was witnessed in new customer enrollment, loan disbursal and repayment rates.

\section{Challenges faced by MFIS post demonetization}

Demonetization may have a lot of long-term benefits and it can be a key drive for creating a digital and cashless economy in long run. However, one cannot deny from the fact that it had a devastating effect on the economy in the short term, especially the microfinance and rural economy. Since most of the MFIs are in rural and sub-urban areas, people deal more with cash than online or digital transactions. Typically, the MFIs have a above average repayment rate of $99 \%$, however, post demonetization it fell almost $12 \%$ below the average repayment rate. Also, there was a sharp increase of $7 \%$ to $10 \%$ in Non-Performing Assets (NPAs) in MFIs. According to ICRAs estimates, the MFIs raised to be an estimate of Rs. 5,500 crores in first six months of FY17, however it was limited to only Rs. 1,650 crores in second half of the year. The negative impacts of the demonization are as follows:

\section{Impact on collections}

As already discussed, MFIs are located in rural and sub-urban areas of the country, where people have less of digital literacy, and they prefer cash over digital banking for their financial transactions. MFIs primarily dealt with cash, lending and recovery of loans were done in cash. Because of $86 \%$ of cash being sucked out of economy during demonetization, MFIs struggled to recover their loans, hence their MFIs witnessed drastic decline in recovery rates immediately after demonetization.

The following Table show the weekly overall collection and disbursements by MFIs

Table 1: Collection and Disbursements by MFIs

\begin{tabular}{|c|c|c|c|c|c|c|}
\hline & $\begin{array}{l}1 \text { Nov to } 6 \\
\text { Nov }\end{array}$ & $\begin{array}{l}7 \text { Nov to } 13 \\
\text { Nov }\end{array}$ & $\begin{array}{l}14 \text { Nov to } 20 \\
\text { Nov }\end{array}$ & $\begin{array}{l}21 \text { Nov to } 27 \\
\text { Nov }\end{array}$ & $\begin{array}{l}28 \text { Nov to } 4 \\
\text { Dec }\end{array}$ & $\begin{array}{l}5 \text { Dec to } 11 \\
\text { Dec }\end{array}$ \\
\hline Collection Efficiency & $99 \%$ & $83 \%$ & $80 \%$ & $109 \%$ & $92 \%$ & $86 \%$ \\
\hline $\begin{array}{l}\begin{array}{l}\text { Disbursement as } \% \text { of } \\
\text { collection }\end{array} \\
\end{array}$ & $80 \%$ & $50 \%$ & $64 \%$ & $82 \%$ & $85 \%$ & $34 \%$ \\
\hline
\end{tabular}

Source: CARE Ratings; Note: Data compiled for 11 NBFC-MFIs

We can see from the table that the collection ratio declined to $80 \%$ in the first couple of weeks post demonetization, but when the RBI announced the release of new currency in the market, in the fourth week, the collection ratio increased. However, we can see that in the subsequent weeks, there is a decline in collection ratios.

We can see in the following table, the drop-in collection ratio from November, 2016 to December, 2016.

Table 2: Collection Efficiency of MFI, Statewise

\begin{tabular}{ll}
\hline State & Collection Efficiency \\
\hline Uttarakhand (UK) & $53.53 \%$ \\
\hline Uttara Pradesh (UP) & $64.35 \%$ \\
\hline Delhi (DL) & $73.50 \%$ \\
\hline Haryana (HR) & $77.23 \%$ \\
\hline Punjab (PB) & $81.23 \%$ \\
\hline Madhya Pradesh (MP) & $84.49 \%$ \\
\hline Rajasthan (RJ) & $84.68 \%$ \\
\hline Maharashtra (MH) & $88.22 \%$ \\
\hline West Bengal (WB) & $90.01 \%$ \\
\hline Himachal Pradesh (HP) & $90.23 \%$ \\
\hline Gujarat (GJ) & $92.96 \%$ \\
\hline Jharkhand (JH) & $94.03 \%$ \\
\hline Others* & $>95 \%$ \\
\hline Average & $84.43 \%$ \\
\hline
\end{tabular}

Source: CARE Ratings; Note: Data compiled for 14 NBFC-MFIs

* includes Kerala, Karnataka, Bihar, Assam, Chhattisgarh, Tripura, Meghalaya, Chandigarh, Tamil Nadu, Puducherry,

Odisha, Goa and Jammu \& Kashmir.

From the above table from CARE Ratings, dated from November, 2016 to December, 2016, we can clearly see that the collection efficiency has drastically drifted downwards, especially for the North Indian States like Uttarakhand, Uttar Pradesh, even Delhi has shown a collection efficiency of $73.50 \%$ which is very low as compared to previous average of $99 \%$. Overall collection efficiency has come down to $84.43 \%$ in the month post announcement of demonetization in November, 2016. 


\section{Impact on lending}

There were tremendous efforts for cashless lending in MFI industry, however, since the digital literacy was lacking among the rural parts and among majority of the poors of the society. Hence it was very difficult for the NBFC-MFIs to disburse the loan amount to its customers. One of the reasons for further decline in the loan disbursement was the withdrawal limit imposed during the first few weeks of currency ban. Because of withdrawal limits on current accounts of MFI, it was difficult for them to disburse the loan amount to its customers.

Another reason for increased impact on lending, is that NBFC-MFIs have focused more on collections than on lending during the study period, hence it was impacted.

\section{Impact on farmers}

Indian population has a strong presence in rural areas, as per the census of 2011 , almost $70 \%$ of India's population lives in rural areas. Agriculture being one of the key contributors to the GDP of the country, with a 17\% contribution of GDP, it can be called as the backbone of the country. As per the Planning Commission of India, 2014, Agriculture and allied sector employs 49\% of the workforce of the country. This industry is mostly dealing in cash-based transactions, with higher denomination currency being sucked out of circulation, this sector was highly impacted. Poor people who had no or limited knowledge and access to banking and post office faced the most brutal impact of this policy.

Farmer's Suicide due to the incapability to repay MFI loans has been a major concern in the country, especially in Southern part of the country. MFI has been strict on its collection policy, sometimes farmers have to borrow money at higher interest rate to repay off MFI loans.

\section{Positive impacts of demonetization on MFIs}

Despite the number of challenges faced by Micro Finance Industry as a whole due to demonetization, however in long run, it is the MFIs only who will benefit the most due to digital receipts and payments. The borrowers will now be forced to use the conventional banking system, then relying on cash-based transactions. Hence, they would be inclusive with the rest of the country in the cashless and digitalization objective of India. More bank accounts were opened under Pradhan Mantri Jan Dhan Yojana (PMJDY), hence supporting the financial inclusion objective. This acted as bridging the gap between the illiterate poors and the advanced banking system of the country. MFIs has been trying to increasingly use the Jan-Dhan accounts for easy and cash-less disbursements and collections.

One of the boost given to the MFI industry, is granting license of Small Finance Bank License to eight of the top MFIs of the country. Which will help this industry to have their own cash out points reaching out to its customer for enhanced usage of their accounts. This step is seen as a major shift to the Micro Finance industry, from cash based to the new-age digital disbursements and collections. There have been numerous efforts by MFIs to educate and aware its customers to make use of banking system and be a part of the conventional banking system.

\section{Conclusions}

After demonetization, the NBFC-MFIs are increasingly looking for cashless disbursement and collection through Jan-Dhan Accounts (opened under PMJDY) and by leveraging technology. With new small bank license awarded to eight of the top NBFC-MFIs, it is going to revolutionalise the entire MFI industry. Cashless disbursement and collection will further fulfil the goal of financial inclusion, by bringing every section of the society into the mainstream banking and financial system. MFI is also actively conducting awareness program through its center and group meetings about the new age banking, and also about the credit profile and its implication on their credit capacity. Those MFIs which have higher financial leverage and have low collection efficiencies are expected to face deterioration in their credit profile in future. From our study, it is clearly evident that Demonetization had an immediate devastating impact on the rural economy, be it rural agriculture economy or micro finance industry. Almost paralyzing the financial transactions in the months just after demonization was announced in November, 2016. The collections were impacted, and it witnessed sharp fall in collection rate to $80 \%$ from $99 \%$ previously. Also, the disbursement of loans was impacted, because of lack of preparedness by the NBFC - MFIs to handle a situation when higher denomination currency was sucked away from the market. The farmers, who are mostly financial-illiterate, and they have less knowledge of banking transactions, faced the most brutal blow. They simply didn't know how to spend on their agriculture, with $86 \%$ of the currency being declared invalid overnight.

Despite of its immediate problems, Demonetization has been claimed to have worked as a stepping stone for Digitalisation and Cashless economy. Millions of financially backward people, now have bank account under PMJDY, thereby strengthening the goal of financial inclusion. One of the biggest beneficiaries of post demonetization is Micro Finance Industry, eight big MFIs were given license by RBI to start new Small Finance Banks. Also, MFI, invested in digitalization, introducing more cash points, online disbursement of loans and accepting direct contributions from its customer online. This increased more transparency and trust for its customers. Demonetization may have caused problems at initial stage, due to lack of proper planning and implementation, but it has laid foundation for a progressive and strong economy. Use of financial services has dramatically increased, there has been increased participation in banking services by people from all walks of life. Research and studies suggest that it will help the financial services 
industry to increased liquidity, and reduce its NPAs, increased use of digital technology in banking and financial services, thus with increased efficiency, enhance the profitability.With a fundamental shift in the formal financial sector, post demonetization. This step is seen as important as the nationalization of banking sector decades ago. It is expected that in next ten years, the small financial banks and the Micro-finance banks will dominate the banking sector in rural India, and will be one of the most important players in overall development of the economy.

\section{References}

Ammannaya, K. K. (2013). Total Financial Inclusion via Financial Literacy. The Southern Econlomist, 51(19).

Bandyopadhyay, A. (2013). Financial Inclusion and Inclusive Growth through Cooperatives. The Cooperator, 50, (4), 1-3.

Banik N, Padalkar M. (2016). India's Demonetization: Time for a Digital Economy, the Diplomat.

Benarji, A. (1988). Towards a Monetary History of India. Economic and Political Weekly, 23(41), 2103-2107. Retrieved April 11, 2021, from http://www.jstor.org/stable/4379150.

Bhatt U. Deshpande O. Panda K. Parmanand P. Prabhumirashi M. (2015). Transacting Jan DhanYojana. Retrieved from https://www.kpmg.com/IN/en/IssuesAndInsights/ArticlesPublications/Documents/PMJDY.

Bhattacharya R. (2016). Demonetization under Incomplete Financial Inclusion, National Institute of Public Finance and Policy.

Chakrabarty K.C. (2013). Financial Inclusion of Urban Poor in India. Reserve Bank of India Monthly Bulletin, P-115.

Chakrabarty, KC (2011). Financial Inclusion and Banks: Issues and Perspective, RBI Monthly Bulletin, 2011.

ChandranVipin K.P. \& Sandhya P. (2013). Strategies of Financial Inclusion Lifecycle in India. The Southern Economist, 51, 19.

Clarke, S. (1998). The Financial System and Demonetization of the Economy. Warwick: University of Warwick, Centre for Comparative Labour Studies.

Deodhar Rahul Prakash. (2016). Black Money and Demonetization. SSRN. http://dx.doi.org/10.2139/ssrn.2869172

Gupta S.K. Ahmad F. \&Mohd. Aslam. (2013). Financial Inclusion - Need of the Hour. Kisanworld, 40(4), 53.

Jain, M., \& Bakshi, I. (2018). Demonetization effect: Microfinance NPAs remain elevated in many states. Business Standard. https://www.business-standard.com/article/economy-policy/demonetization-effect-microfinance-npas-remain-elevated-inmany-states-118041200039_1.html

Kavitha Rao, (2016). Demonetization: Impact on the Economy. National Institute of Public Finance and Policy, New Delhi. 182, 113

Khudir, S. A. (2019). An Empirical Study on Financial Statement Analysis of Myer Holdings and David Jones. International Journal of Advanced Science and Technology. 28, (1), 189-202.

Khudir, S. A. (2019). Elements, Characteristics and Principle for Effectiveness Governance in Public Sector. Indian Journal of Science and Technology, 12 (36), 1-9.

Kishore C. Samal. (1992). Chasing Black Money in India. Journal of Indian School of Political Economy, 4 (2), 319-329.

Kunthia R. (2014). PradhanMantri Jan DhanYojana (PMJDY): A new drive towards financial inclusion in India”. ZENITH International Journal of Business Economics \& Management Research, 4(11), 10-20.

Mahajan P, Singla A. (2017) Effect of Demonetization on Financial Inclusion in India. International Journal of Science Technology and Management. 6(01), 338-343.

Nigam A, (2016). Demonetization, Financial Inclusion and the Great Unbanked, 10 Years of Kafila - Our Common Journey.

Sasi P, Iyer PV (2016). Demonetization effect: Unbanked villages, small businesses badly hit as currency crisi continues, Indian Express, 2016. small-businesses- adly-hit-as-currency-crisis-continues-4385176/

Sharma M. (2016). What Does India'a Demonetization Experiment Mean for Financial Inclusion? Centre for Financial Inclusion Blog.

Singavarapu, A., \& Oncu, T. S. (2013). Challenges to Financial Inclusion in India: The Case of Andhra Pradesh. Economic \& Political Weekly, 48(7).

Singh, C. (2002). Financial Inclusion in India. Indian Institute of Management Bangalore-IIMB WP No.474.

Singh, P. (2013). Depreciation of Rupee in Indian Economy: An Analysis,. International Journal of Innovations in Engineering and Technology (IJIET), 2(4), 332.

Taruna \& N. Kumar (2016). Demonetization in rural areas of Lucknow (U.P): Immediate impact make life difficult to live. International journal of Commerce and Management Research, 3, (4), 100-103.

Singh, P. (2013). Depreciation of Rupee in Indian Economy: An Analysis,. International Journal of Innovations in Engineering and Technology (IJIET), 2(4), 332.

Publisher's Note: SSBFNET stays neutral with regard to jurisdictional claims in published maps and institutional affiliations.

\section{(c) (1)}

() 2021 by the authors. Licensee SSBFNET, Istanbul, Turkey. This article is an open access article distributed under the terms and conditions of the Creative Commons Attribution (CC BY) license (http://creativecommons.org/licenses/by/4.0/).

International Journal of Research in Business and Social Science (2147-4478) by SSBFNET is licensed under a Creative Commons Attribution 4.0 International License. 